\title{
EGFR Mutation in Patients with Lung Adenosquamous Cell Carcinoma
}

\author{
Tomohiro Tamura, MD, PhD, Katsunori Kagohashi, MD, PhD, and Hiroaki Satoh, MD, PhD
}

Mito Medical Center, University of Tsukuba, Mito-city, Japan

\section{TO THE EDITORS}

With great interest, we read the article by Moridomi et al. on clinical significance of detecting somatic gene mutations in surgically resected adenosquamous cell carcinoma of the lung in Japanese patients. ${ }^{1}$ Moridomi et al. reported clinical significance of detecting somatic gene mutations in surgically resected adenosquamous cell carcinoma (ADSQCC) of the lung in Japanese patients. The authors reported that $21.9 \%$ of 32 ADSQCC patients had EGFR mutation, but they did not show the positive rate in adenocarcinoma patients in their study period. Was the positive rate in ADSQCC patients almost the same as that in adenocarcinoma patients? The authors reported relapsefree and overall survival in ADSQCC patients. Please let us know whether there was a relationship between these survivals and the ratio of adenocarcinoma and squamous cell carcinoma components.

We previously reported the case of an ADSQCC patient successfully treated with gefitinib. ${ }^{2}$ In our case, an EGFR exon 19 deletion was identical in adenocarcinoma as well as squamous cell carcinoma components. ${ }^{2}$ With regard to this, we have a strong interest in whether the EGFR mutation in both cell components was identical. The authors discussed the monoclonal origin of both cell type components. ${ }^{3}$ We would like to know whether the authors evaluated the importance of the same EGFR mutation in both cell type components. If so, we would like to know where the authors evaluated EGFR mutation in this study. In addition, where are the best parts of the resected tumor?

\section{REFERENCES}

1. Morodomi Y, Okamoto T, Takenoyama M, et al. Clinical significance of detecting somatic gene mutations in surgically resected adenosquamous cell carcinoma of the lung in Japanese patients. Ann Surg Oncol. 2015;22:2593-98.

2. Kurishima K, Ohara G, Kagohashi K, et al. Adenosquamous cell lung cancer successfully treated with gefitinib: a case report. Mol Clin Oncol. 2014;2:282-84.

3. Kang SM, Kang HJ, Shin JH, et al. Identical epidermal growth factor receptor mutations in adenocarcinomatous and squamous cell carcinomatous components of adenosquamous carcinoma of the lung. Cancer. 2007;109:581-7.
(C) Society of Surgical Oncology 2017

First Received: 4 October 2017;

Published Online: 3 November 2017

H. Satoh, MD, PhD

e-mail: hirosato@md.tsukuba.ac.jp 